\title{
PELTOVILJELYKONEIDEN KÄYTÖSTÄ, KESTOIÄSTÄ JA POISTAMISSYISTÄ
}

\author{
ErkKi H. OKSANen \\ Maatalouden työtekniikan laitos, Helsingin Yliopisto
}

Saapunut 27. 6. 1971

\begin{abstract}
USE AND DURABILITY OF FIELD MACHINES, AND REASONS FOR DISCARDING THEM
\end{abstract}

ERKKI H. OKSANEN

Department of Agricultural Engineering, University of Helsinki

\begin{abstract}
Tractor ploughs, fertilizer spreaders, and mowers were chosen as study machines. The material was collected by farm visits from the same 83 farms in 1959, 1964, and 1969. Larger farms acquired machines proper to new working methods sooner than smaller ones, apart from that they did not have newer machines. The age of machines did not affect the yearly use. The average use in 1969 and the ages in different study years were: tractor ploughs 76 hours, 24.2 hectares, 5.4-5.9 years; spreaders 43 hours, 32.7 hectares, $6.5-9.2$ years; mowers 21 hours, 11.1 hectares, $6.5-8.3$ years. There was a strong positive correlation between amount of use of ploughs and spreaders and the arable land area of the farm. The standard deviation in the amount of use as well as in the age of machines was big. In 1969 the remaining years of use for machines in current use were estimated to be two to four years less than in 1959 for similar machines of the same age.

The average ages of the machines when discarded were: ploughs $8-10$ years, horsedrawn spreaders 14-16 years, tractor spreaders 7-9 years, horse-drawn mowers about 20 years, and tractor mowers $5-7$ years. The main reason for discarding horse-drawn machines was a change over to tractor drawn ones. Tractor machines were discarded chiefly because of a change of the tractor, because of weakness or unsuitability of the machine, or obsoleteness of the model. Only very few of the ploughs and mowers were worn out in use as was sometimes the case with spreaders.
\end{abstract}

Maatilojemme peltoviljely on koneellistunut pääasiassa toisen maailmansodan jälkeen. Kaluston osuus maatalousomaisuudesta oli maatalouden kannattavuustutkimukseen osallistuvilla kirjanpitotiloilla vuosina $1934-38$ vain $7 \%$, tilivuonna $1958 / 59$ jo $13 \%$ ja tilivuonna $196720 \%$ (Tutk. S. maatal. kannattav., tiliv. 1958/59, 1967). Viimeksimainittuna vuonna kirjanpitotilojen koneiden ja kaluston arvo oli $696 \mathrm{mk} / \mathrm{ha}$, josta kasvinviljelykaluston osuus oli n. $44 \%$. Kuinka paljon ja millaisia peltotyökoneita eri kokoisilla tiloilla käytetään, kuinka kauan ne kestävät tai otaksutaan kestävän, ja milloin kone poistetaan käytöstä ja miksi? Näitä seikkoja sekä niissä 1960-luvulla tapahtunutta kehitystä käsitellään tässä selvityksessä traktoriauran, lannoitteen levittimen ja niittokoneen osalta. Kirjoitus on lyhennelmä Maatalouden työtekniikan laitoksen tutkimustiedotteesta N:o 1 (OKsANEN 1971). 


\section{Tutkimusaineisto ja sen käsittely}

Tutkimustiloiksi otettiin vuonna 1959 tapahtunutta aineiston keräystä varten seuraavat vaatimukset täyttäviä kirjanpitotiloja:

- muunnetun maatalousmaan ala oli $10-50$ ha, eli silloisen jaottelun mukaan kyseeseen tulivat II ja III suuruusluokan viljelmät

- tilalla oli traktori, traktoriaura, lannoitteen levitin, niittokone, kylvökone ja perunannostokone.

Myöhemmillä aineiston keräyskerroilla (1964 ja 1969) ei edellämainituista vaatimuksista pidetty kiinni; tärkeämpää oli saada tiedot samoilta tiloilta. Aineistoa saatiin seuraavasti eri tutkimusalueisiin kuuluvilta tiloilta:

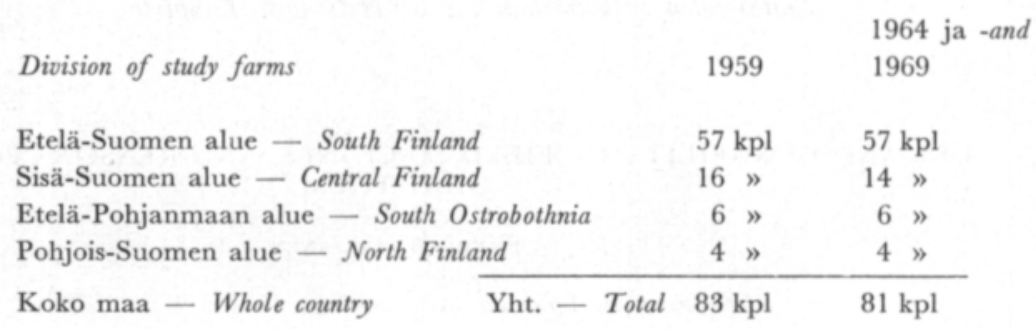

Varsinaisen tutkimusaineiston keräsivät tilakäynnein neuvontajärjestöjen konekonsulentit ja muut neuvojat kevättalvina $1959,-64$ ja -69 . Kutakin tilakohtaista lomakenippua seurasivat täyttöohjeet, joita noudatettiin aika hyvin (OKsANEN 1971). Kirjoittaja suoritti esitutkimuksen parilta tilalta tammikuussa 1959 sekä kävi myöhemmin viidellätoista tilalla tekemässä täydennystiedusteluja.

Yksityiskohtaisen tutkimuksen kohteeksi valittiin lähimain samaa suuruusluokkaa olevat, helposti tarkastettavat, yleiset ja tärkeät peltoviljelykoneet: traktoriaura, lannoitteen levitin (myöh. lyhennys: levitin), niittokone, kylvökone ja perunannostokone. Näistä kaikista täytettiin koneen äärellä sen säilytyspaikassa konelomake. Vuosina 1964 ja 1969 konelomaketta ei täytetty enää kylvö- ja perunannostokoneesta, koska ne eivät näyttäneet antavan oleellista lisätietoa. Lomakkeiden kysymykset olivat vertailukelpoisuuden vuoksi samat kaikilla kerroilla.

Tutkimustilat eivät käytetyn valintamenettelyn takia muodosta satunnaisnäytettä koko maan tiloista tai edes kirjanpitotiloista, eivätkä ole tasaisesti maan eri osiin jakautuneet. Kyseessä on eräänlainen helposti hankittavan ja harkintanäytteen välimuoto: harkinnan perusteella laadittiin luettelo vaatimukset täyttävistä tiloista, joista neuvojat kävivät niin monella kuin ehtivät. Tutkimuksen tuloksia voidaan näin ollen pitää lähinnä suuntaaantavina.

Vuoden 1969 keräyskerran ja lisätiedustelujen jälkeen koko aineistosta laadittiin muuttujamatriisit tietokonelaskentaa varten. Runsaasta tietokonetulostuksesta esitetään vain yhteenvetoja. Täydellinen aineisto on nähtävissä Maatalouden työtekniikan laitoksella Viikissä. Muuttujittaisten lukumäärä- ja prosenttijakautumien lisäksi tehtiin runsaasti 
ristiintaulukointeja. Eräitä tietoja laskettiin lomakkeilta myös niiden tarkastusvaiheessa, kun verrattiin eri vuosina samalla tilalla täytettyjä lomakkeita keskenään.

Hajonta tuloksissa oli yleensä suuri. Havaintomäärät olivat vähäisiä, etenkin jaettaessa tilat peltoalan perusteella useaan luokkaan. Monet havainnot olivat arvionvaraisia, ja niitäkin jäi tarkistuksista ja lisätiedusteluista huolimatta puuttumaan. Aineiston pitkälle vietyyn tilastolliseen käsittelyyn ei näin ollen ollut edellytyksiä.

\section{Tutkimustulokset}

Konemallit ja vuotuiset käyt tömäärät. Tutkimusaikana tapahtui käytettävissä konemalleissa eri syistä aiheutuneita muutoksia. Peltoalan ja konemallin ristiintaulukoinnista oli todettavissa, että käytettävät aurakoot suurenivat tutkimuskaudella, ja että suurilla tiloilla käytettiin suurempia auroja kuin pienillä.

Hevosvetoinen levitin oli traktorikonetta yleisempi alle 20 peltohehtaarin tilaryhmissä tutkimuskauden loppuun saakka, mutta suuremmissa ryhmissä traktorikoneet olivat enemmistönä vuodesta 1964 lähtien. Rivilannoitin oli yleisin lannoituskone v. 1969 jo yli 20 ha:n tutkimustiloilla.

Niittokoneista ei tapaa yhtä selvää tila- ja konekoon suhdetta, sillä hevosvetoisia esiintyi traktorikoneiden ohella kaiken kokoisilla tiloilla koko tutkimuskauden. Niittokone menetti merkitystään 1960-luvulla useasta syystä: viljanviljelyyn erikoistuvat tilat eivät tarvinneet sitä, säilörehun teossa alettiin käyttää niittosilppuria, ja aikaisemmin elonniitossa niittokonetta käyttäneet pientilat siirtyivät puimurin käyttöön.

Auran, levittimen ja niittokoneen käyttömääriä tiedusteltiin isänniltä sekä tunneissa että hehtaareissa laskien. Koneen käyttöala oli ilmeisesti helpompi esittää kuin tunnit, koska se oli jätetty ilmoittamatta vain kuudesosassa lomakkeita; tuntimäärä sen sijaan lähes neljäsosassa. Koneiden käyttömäärien kehitys tutkimuskaudella esitetään taulukossa 1 .

Taulukko 1. Koneiden keskimääräinen käyttö tutkimustiloilla.

Table 1. Average use of machines on study farms.

\begin{tabular}{|c|c|c|c|c|c|c|}
\hline \multirow[t]{2}{*}{$\begin{array}{l}\text { Kone } \\
\text { Machine }\end{array}$} & \multicolumn{3}{|c|}{$\begin{array}{c}\text { Tuntia/vuosi } \\
\text { Hours/year }\end{array}$} & \multicolumn{3}{|c|}{$\begin{array}{c}\text { Hehtaaria/vuosi } \\
\text { Hectares/year }\end{array}$} \\
\hline & 1959 & 1964 & 1969 & 1959 & 1964 & 1969 \\
\hline Traktoriaura - Tractor plough & 75 & 70 & 76 & 18.7 & 18.6 & 24.2 \\
\hline Lann. levitin - Fertilizer spreader & 59 & 48 & 43 & 24.6 & 29.9 & 32.7 \\
\hline Niittokone - Mower & 38 & 25 & 21 & 17.8 & 13.0 & 11.1 \\
\hline
\end{tabular}


Niitetyn alan supistumista seurasi ymmärrettävästi niittokoneen käytön vähentyminen, mutta myös levittimen käyttötuntimäärä supistui runsaasti, vaikka lannoitettu ala lisääntyi. Kynnetyn alan lisäystä ei seurannut auran käyttötuntien lisäys. Edellä todettiin konemallien yleensä suurentuneen ja hevoskoneiden osuuden supistuneen. Kun traktorit myös suurenivat, tuloksena oli nopeampi työnsuoritus. Työnmenekki ha:a kohden on taulukossa 1 esitettyjen lukujen mukaan laskien muuttunut eri töissä seuraavan asetelman mukaisesti:

\begin{tabular}{lllr} 
& \multicolumn{3}{c}{$\begin{array}{c}\text { Työnmenekki tuntia/hehtaari } \\
\text { Work consumption hours/hectare }\end{array}$} \\
& \multicolumn{3}{c}{$\begin{array}{l}\text { (based on Table 1) } \\
\text { (ba) }\end{array}$} \\
& 1959 & 1964 & 1969 \\
Kyntö - Ploughing & & & \\
Lannoitteen levitys - Spreading of fertilizer & 4.0 & 3.8 & 3.1 \\
Niitto - Mowing & 2.4 & 1.6 & 1.3 \\
& 2.1 & 1.9 & 1.8
\end{tabular}

Aurat ja etenkin levittimet sekä niitä käyttävät työmenetelmät kehittyivät traktorien suuretessa; niittokoneissa ei tapahtunut sanottavaa kehitystä 1960-luvulla. Arviokeskimääristä ja eräissä kohdin vaillinaisesta aineistosta lasketut työnmenekkiluvut käyvät yhteen hyvin kaikkina tutkimusvuosina SIPILÄn (1960), Westermarckin (1967) ja Työtehoseuran (Maatalouden työnormit 1970) esittämien kanssa. Ulkomaisissa tutkimuksissa (PARsons ym. 1960, Undersøgelser over..., 1955, Upton 1961) usein todetut suurehkot käyttömäärät johtunevat lähinnä sikäläisestä pitemmästä käyttökaudesta ja suuremmasta tilakoosta. Tässä tutkimuksessa auran ja levittimen käyttömäärät sekä tunneissa että hehtaareissa laskien lisääntyvät selvästi tilakoon suuretessa. Niittokonetta käytettiin pienillä tiloilla vuokratyöhön ja lisäksi muissakin sadonkorjuutöissä kuin heinänteossa. Tästä ja edellä mainituista syistä johtuen tilan peltoalalla ei näytä olleen vaikutusta niittokoneen käyttömäärään.

Vuoden 1969 tulosten perusteella laskettiin luokkakeskimääriä käyttäen korrelaatiokerroin ja lineaarisen regressiosuoran yhtälö käyttömäärän $(y)$ ja tilan peltoalan $(X)$ välille. Korrelaatiokertoimet $(r)$ ja selitysasteet $\left(r^{2}\right)$ olivat:

\begin{tabular}{lccccc} 
& \multicolumn{2}{c}{ Käyttö tuntia/v } & \multicolumn{2}{c}{ Käyttö ha/v } \\
& $\begin{array}{l}\text { Use hours/year } \\
\left.\mathbf{r}^{1}\right)\end{array}$ & $\mathbf{r}^{2}$ 1) & \multicolumn{2}{c}{ Use hectares/year } \\
& & & $\mathbf{r}$ & $\mathbf{r}^{2}$ \\
Aura - Plough & 0.66 & 0.44 & 0.79 & 0.62 \\
Levitin - Spreader & 0.39 & 0.15 & 0.59 & 0.35 \\
Niittokone - Mower & -0.20 & 0.04 & 0.19 & 0.04
\end{tabular}

1) Coefficient of correlation ( $r$ ) and coefficient of determination $\left(r^{2}\right)$ based on use in 1969 , when $x=$ field area and $y=$ amount of use. 
Auran ja levittimen osalta kertoimet ovat merkittäviä (erehtymisriski $<1 \%$; MATTILA 1969); niittokoneen ja tilan peltoalan välillä ei sensijaan ole korrelaatiota tämän aineiston perusteella.

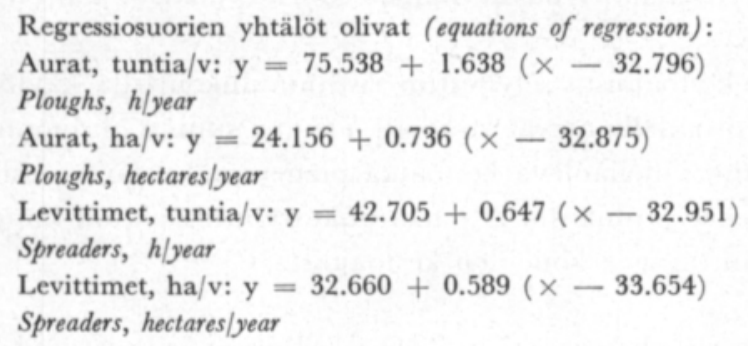

Tilan peltoalan lisääntyessä tai vähentyessä hehtaarilla aineiston keskialasta (= viimeinen luku yhtälössään) muuttuu käyttömäärä keskimäärästä (= yhtälön ensimmäinen luku) vastaavasti regressiokertoimen (= kerroin ennen sulkua) verran. Pinta-alan muutos selittää suuremman osan vuotuiseen käyttöalaan kuin käyttötuntimäärään kohdistuvasta muutoksesta. Tämä on luonnollista, sillä käyttötuntien lisääntyminen ei tilakoon suurentuessa ole yhtä suoraviivaista kuin käyttöalan lisäys, koska suuremmat tilat käyttävät suurempia koneita kuin pienemmät.

K o n e id e n iä t. Keskimääräiset käytössäolleiden koneiden iät olivat seuraavat:

\begin{tabular}{|c|c|c|c|}
\hline & \multicolumn{3}{|c|}{$\begin{array}{l}\text { Keskim. koneiden ikä } \\
\text { Average age of machines }\end{array}$} \\
\hline & 1959 & 1964 & 1969 \\
\hline Aura - Plough & 5.4 v. $y$. & 5.9 v. $y$. & 5.9 v. $y$. \\
\hline Levitin - Spreader & $7.6 》$ & $9.2 "$ & $6.5 》$ \\
\hline Niittokone - Mower & $6.5 »$ & $8.3 "$ & $8.2 "$ \\
\hline
\end{tabular}

Uusien rivilannoittimien määrä, joka oli melko suuri, alensi levittimien keski-ikää v. 1969. Niittokoneiden ja levittimien keskimääräiset iät olivat koko tutkimusaikana huomattavasti korkeampia kuin aurojen. Tämä johtui vanhojen hevoskoneiden mukanaolosta: v. -59 hevosvetoiset levittimet olivat keski-iältään lähes 10 -vuotisia ja niittokoneet yli 15-vuotisia, vuonna - 64 vastaavasti 13 - ja lähes 20 -vuotisia. Traktorikäyttöiset vastaavat koneet olivat lähimain aurojen ikäisiä eli keski-iältään 4.2-7.0 vuotta. Vanhat hevoskoneet aineistossa nostivat myös levittimien ja niittokoneiden ikien keskihajontaa, joka oli auroilla 3.0 - 4.5 vuotta ja toisilla $4.5-6.0$ vuotta.

Kirjoittaja on todennut traktorin käytön supistuvan sen vanhetessa (OKsANEN 1963). PARsons ym. (1960) ovat päätyneet samaan tulokseen myös työkoneiden osalta. Yksittäisen vuoden ja koneen kannalta ristiintaulukointia tarkasteltaessa voisi tässä tutkimuksessa toisinaan väittää samaa. Esim. vuosina 1964 ja 1969 alle 5-vuotisia auroja ja levittimiä käytettiin yleensä enemmän kuin vanhempia koneita. Tämä ei kuitenkaan ole riippuvainen koneiden iästä sinänsä vaan uusien työmenetelmien käyttöönotosta ja niihin liittyvien konemallien hankinnasta suurehkoille tiloille, joilla niille tulee runsaasti käyttöä. Ilman tällaisia muutoksia koneen iällä ei näytä olevan sanottavaa vaikutusta koneen käyttömäärään, eivätkä myöskään suuremmilla tiloilla koneet ole muutoin nuorempia kuin pienemmillä. 
Edelläsanottua vahvistaa niittokoneiden tarkastelu. Niissä ja kuivan heinän korjuussa ei tapahtunut sellaisia muutoksia, jotka olisivat tehneet 1950-luvulla hankitut traktorikoneet tai käytetyt työmenetelmät vanhanaikaisiksi. Yli 10-vuotisia koneita esiintyi kaiken kokoisilla tiloilla ja niiden käyttömäärät olivat samaa suuruusluokkaa kuin nuorempienkin.

Viljelijöiden arvioita koneidensa kestoajoista selvitettiin ristiintaulukoimalla käytössä olevien koneiden iät ja niiden odotetut jäljellä olevat kestoiät. Yleinen suunta oli luonnollisesti, että vanhoille koneille arvioitiin jäljelläoleva kestoaika pienemmäksi kuin uusille. Poikkeamia tästä silti oli, kuten ilmenee taulukosta 2, jonka päätarkoituksena on kuitenkin esittää isäntien mielipiteiden muuttumista koneiden kestoajoista.

Taulukko 2. Eri ikäisten käytössä olevien koneiden arvioidut jäljelläolevat kestoajat.

Table 2. Estimated remaining years of use for machines of different ages.

Käytössä olevien koneiden ikä vuotta Age of machines in use, years
Odotettu jäljelläoleva kestoaika vuotta Estimated remaining years of use

\begin{tabular}{|c|c|c|c|c|c|c|c|c|}
\hline \multicolumn{3}{|c|}{$\begin{array}{l}\text { Aura } \\
\text { Plough }\end{array}$} & \multicolumn{3}{|c|}{$\begin{array}{c}\text { Lann. levitin } \\
\text { Spreader }\end{array}$} & \multicolumn{3}{|c|}{$\begin{array}{c}\text { Niittokone } \\
\text { Mower }\end{array}$} \\
\hline-59 & -64 & -69 & -59 & -64 & -69 & -59 & -64 & -69 \\
\hline 11.6 & 10.6 & 7.3 & 10.0 & 8.4 & 8.0 & 12.2 & 11.2 & 8.9 \\
\hline 10.0 & 8.5 & 8.0 & 7.7 & 6.7 & 7.1 & 9.1 & 11.4 & 8.9 \\
\hline 8.1 & 8.3 & 5.2 & 7.8 & 6.0 & 6.9 & 7.8 & 6.2 & 8.7 \\
\hline \multirow[t]{2}{*}{9.3} & 6.7 & 5.8 & 7.0 & 6.0 & 4.2 & 10.8 & 4.9 & 6.5 \\
\hline & & & 5.6 & 4.7 & 3.7 & 8.2 & 5.5 & 4.4 \\
\hline
\end{tabular}

Yhtä poikkeusta (5-8-vuotiaat niittokoneet) lukuunottamatta kunkin ikäluokan koneiden jäljelläoleva kestoaika arvioitiin v. 1959 suuremmaksi kuin v. 1969. Vuonna 1969 arvioitiin uusille koneille $2-4$ vuotta ja $9-15$ vuotisille $3-4$ vuotta lyhyempi jäljelläoleva kestoaika kuin v. 1959. Aurojen ja niittokoneiden jäljelläolevat kestoajat arvioitiin eri ikäluokissa yleensä korkeammiksi kuin levittimien.

Vaikka vanhempien koneiden jäljelläoleva kestoaika arvioitiinkin yleensä lyhyemmäksi kuin nuorempien, ero oli koneiden todellista ikäeroa pienempi. Tästä esimerkkinä esitetään vuoden 1964 tietojen perusteella laskettu asetelma:

Koneiden ikä
vuotta
Age of machines,
years
$\begin{gathered}0-2 \\ 5-8 \\ >15\end{gathered}$

\begin{tabular}{|c|c|c|}
\hline \multicolumn{3}{|c|}{ Ikä + jäljellä oleva kestoaika vuotta } \\
\hline Aura & Levitin & Niittokone \\
\hline Plough & Spreader & Mower \\
\hline & & \\
\hline 13 & 9 & 12 \\
\hline 15 & 13 & 13 \\
\hline $\left.19^{1}\right)$ & $>20$ & $>20$ \\
\hline
\end{tabular}

1) 9-15-vuotiset aurat - Ploughs 9-15 years old 
Arviot koneiden kokonaiskestoajasta muuttuivat kokemuksen karttuessa ja työmenetelmien sekä konemallien vaihtuessa. Hevoskoneille arvioitiin 5-10 vuotta $(30-100 \%)$ korkeampia kokonaiskestoaikoja kuin vastaaville traktorikoneille, ja hevoskoneiden pitkäaikainen käyttö vahvisti arvion oikeaksi. Hevoskoneista kuitenkin luovuttiin. Kirjoittaja on todennut tärkeimmäksi maatalouden koneellistamisen syyksi töiden nopeasti ja ajallaan suorittamisen (OKSANEN 1963). Hevosvetovoima oli saattanut maataloustöiden nopeuttamismahdollisuudet lähimain stagnaatiotilaan; motorisointi vapautti tästä.

Koneiden käytöstä poistamisiät ja -syyt. Vuoden 1969 ilmoitusten mukaan traktoriaurojen ikä oli käytöstä poistettaessa vuotta:

In -69 age of tractor ploughs when discarded, years:

\begin{tabular}{|c|c|c|c|c|c|c|c|c|c|c|}
\hline & & $0-4$ & $5-6$ & $7-8$ & $9-10$ & $11-12$ & $13-14$ & $15-17$ & $>17$ & $\begin{array}{l}\text { Yht. } \\
\text { Total }\end{array}$ \\
\hline Poist. kpl & & 9 & 12 & 10 & 17 & 6 & 6 & 7 & 3 & 70 \\
\hline Discarded, & number & & & & & & & & & \\
\hline$"$ & $\%$ & 13 & 17 & 14 & 24 & 9 & 9 & 10 & 4 & 100 \\
\hline
\end{tabular}

On selvää, ettei ainakaan alle 7-vuotisia traktoriauroja poistettu loppuunkuluneina. Poistamisen syyt ja poistamistavat ristiintaulukoitiin konemallien kanssa. Hevosaurojen kohdalla syynä oli ymmärrettävästi siirtyminen traktorivetoisiin. V. -59 ilmoitettiin käytöstä poistetut hevosaurat jätetyn usein vara- tai apuauroiksi tilalle. Myöhemmin ne, siis samat aurat, ilmoitettiin romutetun; odotettua vara- tai apukäyttöä ei ilmeisesti esiintynytkään. Traktoriaurojen poistamissyiden kehitys on mielenkiintoinen:

Traktoriauran poistamisen syy

Reasons for discarding tractor plough

\begin{tabular}{|c|c|c|c|}
\hline \multirow[t]{2}{*}{ Reasons for discarding tractor plough } & \multicolumn{3}{|c|}{$\%$ of cases } \\
\hline & 1959 & 1964 & 1969 \\
\hline Traktori vaihdettu - Change of tractor & 40 & 38 & 20 \\
\hline Heikko tai sopimaton - Weak or unsuitable & 45 & 30 & 26 \\
\hline Vanhentunut malli - Obsolete model & 5 & 20 & 26 \\
\hline Hankittu suurempi - Bigger one purchased & 5 & 4 & 16 \\
\hline Loppuun käytetty - Worn out & - & 8 & 12 \\
\hline Muuta - Others & 5 & - & 一 \\
\hline Yht. - Total & 100 & 100 & 100 \\
\hline Aineiston suuruus $\mathrm{kpl}-$ Number of ploughs & 22 & 50 & 58 \\
\hline
\end{tabular}

Traktorin vaihdon osuus syynä supistui; osansa tässä lienee nostolaitteiden standardisoinnilla. Aikaisemmin aura oli usein heikko tai tilan traktoriin sopimaton. Myöhemmin aura vaihdettiin yhtä usein mallin vanhentuneisuuden takia. Yhdessä nämä kaksi syytä vastasivat $50 \%$ poistotapauksista. Traktoriauroja poistettaessa ne yleensä vaihdettiin traktorin mukana tai myytiin muuten käyttöön. Vuosina -64 ja -69 ilmoitettiin joitakin jätetyn vara- tai apuauroiksi ja muutamia romutetun.

Hevoslevittimien käytöstä poistamisen iäksi tuli keskimäärin 14-16 vuotta eri kerroilla, traktorilevittimien 7-9 v. Hajonta etenkin traktorilevittimien kohdalla oli suuri. Slaterin (1957) tutkimuksessa traktorilevittimien poistoikä Englannissa oli 13.6 v. Hevoskoneiden käytöstä poistamisen pääsyiksi ilmoitettiin v. 1959 koneen tulleen loppuunaje- 
tuksi tai sen olleen sopimaton tai heikko. Myöhempinä vuosina siirtyminen traktorikoneisiin osoittautui suurimmaksi syyksi, mutta loppuunajettuja koneita oli myös useita. Poistamistavoista yleisin oli myynti käyttöön, sitten romutus. Muutamia ilmoitettiin jätetyn vara- tai apukoneeksi traktorilevittimien rinnalle.

Traktorikoneiden poistamisen syinä mainittiin useimmiten koneen heikkous tai sopimattomuus tilalle. Joitakin loppuunajettuja koneita oli myös. V. 1969 esiintyi syynä mallin vanhentuneisuus, ilmeisesti eräillä rivilannoitukseen siirtyneillä tiloilla. Käytöstä poistettuja traktorilevittimiä oli yleisesti jätetty vara- tai apukoneeksi, muutamia myös myyty käyttöön tai romutettu. SLATERin (1957) tutkimustiloilla levittimet oli poistettu loppuunkuluneina ja romutettu.

Hevosniittokoneiden poistamisikä oli 18-20 vuotta ja yleisin syy oli traktorikäyttöisiin siirtyminen, n. $80 \%$ tapauksista. Loppuunajettuja oli lähes $20 \%$. Poistamistavaksi vuosina 1959 ja 1964 ilmoitettiin yleisimmin vara- tai apukoneeksi jättäminen. Myös romutus ja käyttöön myynti esiintyivät usein. V. 1969 mainittiin vain nämä kaksi tapaa. Kuten hevosauratkin, aikaisemmin vara- tai apukoneeksi jätetyt hevosniittokoneet myöhemmin usein romutettiin, kun vara- tai apukäyttöä ei tullut, eikä ollut enää hevosiakaan sitä varten.

Traktorikoneiden v. 1959 keskim. 3- ja myöhempinä vuosina 7-9-vuotiaana tapahtuneen poistamisen syyksi ilmoitettiin lähes $50 \%$ :ssa tapauksista koneen heikkous tai sopimattomuus ja yli $40 \%$ :ssa traktorin vaihto. 3-4 konetta oli loppuunajettuja, ja pari poistettu v. 1969 mallin vanhentuneisuuden takia. Muita sekalaisia syitä aina tulipaloa myöten esiintyi vuosina 1964 ja 1969 yhteensä kuuden koneen kohdalla. Poistamistapoina olivat yleisimpiä myynti käyttöön toiselle tilalle tai luovutus traktorin mukana sitä vaihdettaessa. Kymmenkunta konetta ilmoitettiin romutetun ja viisi jätetyn vara- tai apukoneeksi, ilmeisesti niittosilppurille.

Käytöstä poistettujen hevoskoneiden joukosta löytyi todellisia vanhuksia. Mm. 49vuotias niittokone ja 36-vuotias levitin oli poistettu käytöstä traktorikoneeseen siirtymisen vuoksi. Traktorikoneita moititiin enemmän. Niitä ei 1950-luvulla osattu/voitu/haluttu/ kannattanut jne. rakentaa riittävän lujiksi kestämään niitä rasituksia, joita traktoreiden tehon, painon ja ajonopeuden lisäys aiheuttivat. Todettakoon kuitenkin, ettei traktorikoneiden heikko kesto ollut aina koneiden syytä: parissa tapauksessa kone särkyi puuhun tai viemäriinajon seurauksena.

Vuoden 1969 aineistoa aikaisempiin verrattaessa saatettiin todeta, että koneita poistettiin usein käytöstä ennen kuin edellisten kertojen ko. konetta koskeva »odotetaan kestävän vielä vuotta»-aika-arvio oli mennyt umpeen. Auroista yli $90 \%$ poistettiin ennen arvioidun kestoajan päättymistä. Näissä tapauksissa noin puolet oli poistettu, kun kestoaikaa olisi ollut jäljellä vielä 5 vuotta tai enemmän. Syynä oli silloin etupäässä traktorin vaihto tai auran sopimattomuus, harvoin loppuunkuluneisuus.

Levittimissä ja niittokoneissa ennen arvioidun kestoajan päättymistä tapahtunut käytöstä poistaminen ei ollut niin yleistä kuin auroissa, mutta niistäkin yli puolet poistettiin tätä aikaisemmin, ja vain n. kuudesosa $1-4$ vuotta sen jälkeen. Kolmasosa niittokoneiden poistamisista osui kestoajan päättymisen ajankohtaan. Ennen arvioidun kestoajan päättymistä kone poistettiin lähinnä sopimattomuuden, traktorin vaihdon tai koneen vanhentuneisuuden, mutta aika usein myös loppuunkuluneisuuden takia. Käytöstä poistettaessa traktorin vaihdon, koneen sopimattomuuden tai varakoneeksi siirtämisen takia yli puolet 
tutkimuskohteista oli vielä käyttökunnossa, joten niillä todellisuudessa oli kestoaikaa jäljellä, joskaan ei siinä tehtävässä, mihin ne alun perin tilalle hankittiin. Ilmeiseltä näyttää kuitenkin suunta: Koneet poistettiin käytöstä odotettua ja oletettua aikaisemmin.

Tutkimuksessa käsitellyllä 10-vuotiskaudella tapahtunut kehitys antaa myös aiheen uskoa, että viljelijät pyrkivät jatkuvasti nopeuttamaan työsuorituksiaan etenkin kiirekausina. Työtekniikan laitoksen tutkimuksissa (LAtostenmaA 1970, Pehkonen 1971) on osoitettu, että koneen suurentaminen ei ole tällöin aina tarpeen. Suhteellisen vähäisillä muutoksilla koneiden rakenteessa sekä paremmalla töiden järjestelyllä ja suoritustekniikalla päästään hyviin tuloksiin. Silloin toisaalta voivat, ellei tilojen koko suurene tai koneiden monitilakäyttö lisäänny, koneiden pienet vuotuiset käyttötuntimäärät entisestäänkin supistua. Ratkaisevaa ei kuitenkaan ole, kuinka monta tuntia konetta vuodessa käytetään, vaan mitä sillä silloin saadaan tehdyksi ja kuinka hyvin.

\section{Ti ivistelmä}

Tutkimuksessa haluttiin selvittää, kuinka paljon ja millaisia peltoviljelykoneita eri kokoisilla tiloilla käytetään, kuinka kauan konetta pidetään ja miksi se poistetaan käytöstä, sekä millainen on ollut kehitys näiden seikkojen suhteen 1960-luvulla. Tutkimuskoneina olivat traktoriaura, lannoitteen levitin ja niittokone. Aineisto kerättiin koko maasta tilakäynnein samoilta tiloilta vuosina 1959, 1964 ja 1969. Tutkimustiloja oli 83 kpl, muunnetun maatalousmaan alaltaan v. $195910-50$ ha. Ne eivät muodostaneet määrättyä otosta. - Tuloksia:

Käytettävät aurakoot suurenivat tutkimuskaudella, ja suuremmilla tiloilla käytettiin suurempia auroja kuin pienillä. Rivilannoitin yleistyi nopeasti tutkimuskauden lopulla yli 20 pelto-hehtaarin tiloilla. Niittokoneet olivat samanlaisia eri kokoisilla tiloilla. Suuremmat tilat hankkivat nopeammin uusien työmenetelmien edellyttämiä koneita kuin pienemmät, ja suurilla niille tuli runsaasti käyttöä. Muuten koneen iällä sinänsä ei ollut vaikutusta vuotuiseen käyttömäärään, eikä suuremmilla tiloilla ollut yleensä uudempia koneita kuin pienemmillä.

Hehtaareissa laskien auran ja levittimen käyttömäärät lisääntyivät, niittokoneen supistui. Levittimen ja niittokoneen käyttötuntimäärät vähenivät traktorikoneiden yleistyessä. V. 1969 koneiden keskimääräinen käyttö oli:

$\begin{array}{lll}\text { Traktoriaura } & 76 \text { tuntia/v } & 24.2 \mathrm{ha} / \mathrm{v} \\ \text { Lannoitteen levitin } & 43 \mathrm{n} & 32.7 \mathrm{~m} \\ \text { Niittokone } & 21 \mathrm{n} & 11.1 \mathrm{~m}\end{array}$

Auran ja levittimen käyttömäärien ja tilan peltoalan välillä oli vahva positiivinen korrelaatio.

Tutkimustiloilla käytössäolleiden koneiden keskimääräiset iät olivat:

\begin{tabular}{|c|c|c|}
\hline & 1959 & 1964 \\
\hline Traktoriaura & $5.4 \mathrm{v}$ & $5.9 \mathrm{v}$ \\
\hline Lannoitteen levitin & $7.6 ”$ & $9.2 »$ \\
\hline Niittokone & $6.5 n$ & $8.3 "$ \\
\hline
\end{tabular}


Levittimien ja niittokoneiden keski-ikää kohottivat aineistossa mukanaolleet hevoskoneet; traktorikoneet olivat aurojen ikäisiä. Keskihajonta niin ikien kuin käyttömäärienkin suhteen oli suuri. V. 1969 arvioitiin käytössä oleville koneille 2-4 vuotta lyhyemmät jäljellä olevat kestoajat kuin samanikäisille koneille v. 1959.

Keskimääräiset käytöstä poistamisiät olivat: aurat 8-10 v, hevoslevittimet $14-16 \mathrm{v}$, traktorilevittimet $7-9 \mathrm{v}$, hevosniittokoneet $\mathrm{n}$. $20 \mathrm{v}$ ja traktoriniittokoneet $5-7 \mathrm{v}$. Poistamisikien hajonta oli erittäin suuri. Hevoskoneiden käytöstä poistamisen pääsyy oli traktorikoneisiin siirtyminen. Hevoskoneista useimmat romutettiin heti tai myöhemmin. Traktorikoneet poistettiin lähinnä traktorin vaihdon, koneen heikkouden tai sopimattomuuden tai mallin vanhentuneisuuden takia. Loppuunkuluneita oli poistetuista auroista ja niittokoneista vain aniharva, levittimistä useampia. Traktorikoneet myytiin tavallisesti käyttökoneeksi. Koneet poistettiin käytöstä yleensä ennen odotetun kestoajan päättymistä ja ilmeisesti myös arvioitua aikaisemmin.

Kustannus- ym. konelaskelmissa voidaan käyttää normilukujen ja käyttöpinta-alojen perusteella laskettavia vuotuisia käyttötuntimääriä. Mallien vanhentumisen takia yli 10 vuoden kestoikiä ei suositella käytettäväksi laskelmissa peltoviljelykoneille.

\section{KIRJALLISUUTTA}

LAtostenmaA, H. 1970. Sivuaika työsaavutukseen vaikuttavana tekijänä rivilannoitus- ja kylvölannoitustöissä. Konekirj. 71 s.

Maatalouden työnormit. 1970. Työtehoseuran julk. 144: $1-42+4$ liit.

Mattila, S. 1969. Tilastotiede I. 272 s. Helsinki.

OкsAnen, E. H. 1963. Koneellistamisen vaikutuksia työnmenekkiin ja organisaatioon Etelä-Suomen kirjanpitotiloilla. S. Maat. Tiet. Seur. Julk. 101: 1-170+16 liit. Diss.

—»— 1971. Peltoviljelykoneiden käytöstä, kestoiästä ja poistamissyistä. Maatal. työtekn. lait. tutk. tied. 1: 1-42. Moniste.

Parsons, M., S. Robinson, F. H. \& Strickler, P. E. 1960. Farm machinery: Use, depreciation and replacement. U. S. D. A. Statist. Bull. 269: 1-37.

Pehkonen, A. 1971. Rivilannoitus ja kylvölannoitus työteknisinä ratkaisuina. Konekirj. $114 \mathrm{~s}$.

SIPIL Ä, M. 1960. Maatilan työoppi. Työtehoseuran julk. 89: 1-251.

Slater, J. K. W. 1957. A survey of fertilizer distributors and combine drills. J. Agric. Engin. Res. 2: 294298.

Tutkimuksia Suomen maatalouden kannattavuudesta. Tilivuodet 1958/59, 1967.

Undersegelser over landbrugets driftsforhold. 1955. Periodiske Ber. XI: $1-39+$ hovedtabeller.

Upton, M. 1961. An investigation into the fuel consumption and use of diesel tractors on eight Berkshire farms. J. Agric. Engin. Res. 6: 123-129.

Westermarck, N. 1967. Viljelijän suunnitelmaopas. Maatal. Seur. Keskusl. Julk. 535: 1-176. 